\title{
A Study on the Difficulties of Developing English Speaking Abilities among Chinese Tertiary EFL Students
}

\author{
$\mathrm{Xu}$ Wenyu \\ School of Foreign Language \\ North China Electric Power University \\ Beijing, China \\ 845899256@qq.com
}

\begin{abstract}
Globalization has greatly stimulated the demands and enthusiasm for learning English in China, thus the use of English has greatly increased with China's strong desires to be the crucial character at the world stage. English plays a key role in many different fields, such as politics, economics and education. As for education, more and more college students are aware that English is an important medium which can help them further study. However, due to the lack of instructions and systematic learning methods, how to learn English effectively and efficiently at university, especially oral English, is still a troublesome problem for many college students. This paper explores the styles of learning English among Chinese EFL students in China's university context based on investigation data, analyzes the challenges relating to oral English Chinese EFL students during learning process, traces these factors back to their learning experiences, and finally gives recommendations on how to take full use of surrounding resources to develop English speaking ability for Chinese tertiary schools in the future.
\end{abstract}

Keywords-Chinese tertiary EFL students; Oral English; Speak Fluently; Learning Motivation

\section{INTRODUCTION}

According to an investigation conducted at a university in Mainland China [1] college students prefer to learn English through some visual and tactile activities such as reading books, learning the teaching materials and doing related exercises under teachers' instructions. Because Chinese people are deeply influenced by the thought of Confucius who advocated respecting teachings in class without interruptions, Chinese students tend to listen carefully as English teacher is an authority in English class [2], which results in more emphasis on input rather than output. In this way, most of Chinese tertiary EFL students show better abilities in reading and listening but they are weak in writing and speaking comparatively.

At most universities, there are only few English courses provided during freshman and sophomore period. These English courses are mainly aimed at helping students pass CET-4 and CET-6 exams which do not require speaking ability, usually in the form of lectures, lack of any other teaching and learning styles like group project, group project and so on. In this way, students only learn skills to pass standardized exams passively in lectures, and they cannot develop English speaking ability due to the lack of opportunities to output, thus weak in oral English.

\section{DIFFICULTIES IN ORAL ENGLISH AMONG CHINESE TERTIARY EFL STUDENTS}

The word order in Chinese is hugely different from that in English, as there are set word orders from cause to effect, form condition to result etc. in Chinese, while English word order is more flexible, it is hard for Chinese to organize well-sounded sentences with decent word order [3]. When concentrating on the sentence structure and word order in sentences, sometimes it is hard for EFL students to organize sentences in correct word order with correct usages of parts of speech [4].

Ellis [5] points out that there are two types of error analysis that can be used to analyze problems in learning and using foreign language, in which one is grammaticality and another is acceptability. In linguistics, grammaticality refers to the conformity of a sentence to the rules defined by a specific grammar. For acceptability, it requires speakers to speak in an acceptable way that fits in the situational contexts. The first weakness among most Chinese tertiary EFL students is influent language flow and incoherent answers. Lack of input can lead to insufficient ability in output. As most Chinese tertiary EFL students study in a Chinese-speaking context every day, they have comparatively small chances to get themselves exposed to sufficient amount of English in daily life and study life. As for incoherency, when EFL students cannot find adequate words in their repertoire of vocabulary or cannot organize sentences in a logical way, they tend to answer questions or express themselves in an incoherent way with limited words they know and broken grammar structures.

The second weakness of most Chinese tertiary EFL students in oral English is the misuse of many types of inflectional affixes Many Chinese tertiary EFL students make inflectional affixes errors in third person singular "s", plural "s" and present participle "ing" in verbs. Although many students know the explicit English grammar rules for they have learned grammar rules in details to pass the college entrance examination, they often make errors unconsciously in oral English. Presumably the original source of error in inflectional affixes should be the great differ- 
ences between the learner's native language and the target language, for many Chinese tertiary EFL students find it difficult to immediately distinguish and apply the grammatical rules of inflections which do not have distinct features in their native language Mandarin [6]. In the meanwhile, the concept of interlanguage can also account for this problem, for Chinese tertiary EFL students may be influenced by the characteristics of English itself and the way they were taught when they learned inflectional affixes [7].

The third salient weakness is about pronunciation, for example, incorrect pronunciation of vowels and habitual omission of final consonant clusters. Some Chinese tertiary EFL could produce vowel sounds in good manners and cannot distinguish some minimal pairs like bed and bad. For final consonant clusters, sometimes Chinese tertiary EFL students put too much emphasis on the final consonant clusters, in this way the word "stop" [stop] is always pronounced as [stppu] in international phonetic alphabet [8]. Another problem is the habitual omission of final consonant clusters, and in this way the word "communicate" is pronounced as [kə'mju:nıkeI], whereas the correct pronunciation should be [kə'mju:nikeIt]. The reason for these two phenomena could be traced back to Chinese tertiary EFL students' first language Chinese where few final consonants exist, and evidence has been found that Chinese speakers tend to abandon the final consonant clusters and produce a slight glottal or unreleased stop as mentioned above [9]. However, Cook [10] also argues that many L2 learners generally prefer to omit final consonant clusters, and James, Doorn, Mcleod, and Esterman [11] also report that $66 \%$ of all consonant omission happens at the end of the words, hence a universal tendency instead of transfer from first languages. In combination, it is wise to ascribe this weakness to the characteristics of English itself, however, Chinese tertiary EFL students' L1 can be not neglected in the process of learning and output.

\section{III.FACTORS THAT ATTRIBUTE TO THESE DIFFICULTIES}

Individual factors can vary a lot as learners grow older, as many factors have contributed to Chinese tertiary EFL students' English learning in different phases, hence difficulty in finding a factor that impacts the whole process of SLA constantly. However, it is relatively objective and practical to value the individual factors on SLA through learner's recent learning experience in university context. Four major factors are salient that contribute to the recent experience of learning English, including motivation, personality, L1/L2 differences and learning environment

\section{A. Motivation}

Firstly, motivation is the key factor that contributes mostly to English learning. Motivation in second language learning is a complex phenomenon for it involves several respects of small factors, and motivation can be divided into two types, instrumental motivation and integrative motivation [12]. Some students have to develop their speaking ability in English to hunt for a decent job in the near future where they will probably use English as an important tool or medium. Simultaneously more and more Chinese tertiary EFL students are planning to apply for postgraduate study in an English-speaking country, therefore they need to improve their speaking ability in English to adapt to the study environment in the future. These two goals are for immediate or practical purposes which belong to instrumental motivation. It is worth noting that there are also some Chinese tertiary EFL students who have integrative motivation as well due to pure interests in English language itself or wants to integrate into English communities one day. Generally speaking, when students are constantly motivated, they would focus on improving their speaking skill. If students possess any intrinsic motivation, which is different from instrumental motivation, as no utilitarian or practical purposes for learning English [13], they would also push themselves to polish their oral English skills. Otherwise, Chinese tertiary EFL students would find it extremely hard to develop oral English on the condition that they do not have any kind of motivation in a Chinese-speaking environment.

\section{B. Personality}

$\mathrm{E}$ The second influential individual factor is personality. Firstly, for the relationship between performance and personality, evidence has pointed out that extroverts do better on oral than written level [14]. Com-pared with western people, Asians tend to be shy and inner-going in social practice and communications in study and daily life, and this kind of personality is not beneficial for language study. If with extroversion, students would have many opportunities to practice and improve their oral English in different English activities, such as English corner at university and English speech contest, even with a limited amount of fluency. But most Chinese tertiary EFL students confine themselves to their comfort zone due to their introvert personality, thus less and less chances to practice oral English. Moreover, anxiety is closely linked with personality and it can affect the process of language learning in any types of context [6] However, anxiety is not totally negative, as a controlled amount of tension brought up by anxiety can be viewed as both positive and negative [15]. If one is positive and light-hearted, one's personality would help a lot to balance anxiety and continuous English learning, and a certain amount of tension intrigued by anxiety also pushes one to learn English to some extent. Most Chinese tertiary EFL students would feel anxious every time they recognize the mistakes they made in oral English, which really reduces their confidence in learning English, but those who have positive character would adjust the anxiety properly and be ready to welcome next opportunities of English learning after a short period of time.

\section{Differences between L1 and L2}

Thirdly, the great differences between L1 and L2 plays a fundamental role in Chinese tertiary EFL students' English learning experience. As mentioned in summary part, Chinese tertiary EFL students' L1 influences their English output, especially the pronunciation and inflectional affixes. First, Chinese is hugely different from English in pronunciation system, as students often ignore some pronunciation phenomena which Chinese does not have, such as consonant clusters. Second, due to the fact that there are some special sounds in some students' dialect of mandarin, some other sounds that do not exist in the dialect can be confusing for students to distinguish and speak out. For example, there is only [1] sound in the southern dialect of mandarin, thus [1] and [n] sounds are undistinguishable for Chinese students in southern China, so they always struggle to pronounce this pair of sounds with great effort [9]. Moreover, as Chinese does not have from inflectional affixes, Chinese speakers tend to make many errors in inflection changes [16]. For example, as third 
person singular "s" is abundant in English language and does not appear in Chinese language, Chinese tertiary EFL students often omit it in language flows in sentences even though they learnt this language point at the very beginning of their English class in primary school or junior high school.

\section{Learning Environments}

Finally, learning environment as an external factor influences the amount of time to get exposed to English, thus the efficiency of developing oral English. As mentioned in the summary part, English courses at university focus mainly on practical skills to pass the standardized exams, thus lack of any other teaching and learning styles, such as group project and group project. Insufficient opportunities for students to utilize and practice what they learn in class in the form of speaking. After class, there are less chances for students to get exposed to English and speak English, for Chinese tertiary EFL students live in a Chinese-speaking context and it is not easy for them to find a language partner to practice oral English.

\section{RECOMMENDATIONS}

To conclude, there are some constructive suggestions for Chinese tertiary EFL students to consider to develop oral English ability.

\section{A. Shadowing and 4-3-2 activity}

For students who do not notice their problems on pronunciation, first of all it is necessary to help them know where the problems lie and then practice speaking with effective speaking activities, among which shadowing is recommended. Chi-nese tertiary EFL students can conduct phonemic shadowing regularly, in which they can repeat each sound immediately they hear the text without hearing the complete forms of the phrase or the sentence [17]. With the record of shadowing repetition and comparison with original tape afterwards, it is easy for students to diagnose the pronunciation problems themselves, then she can make improvements next time. Other speaking activities can also help with pronunciation, such as 4-3-2 activity and single sounds practice [18].

\section{B. Interaction and feedback}

More importantly, learning through interaction and feedback is recommended. Analysis shows most Chinese tertiary EFL students roughly know some of the grammar rules but they are still not totally clear about the use of inflection affixes. In this circumstance, students are suggested to grasp opportunities to communicate English native speakers or language teachers and get feedback from them, including explicit corrections, recasts reformulating, clarification and metalinguistic feedback etc. [19]. Chinese tertiary EFL students can conduct this plausible suggestion at university as there are English Corner activities and diverse types of English events back at university in China where they can also learn English and get feedback in an authentic English context from peers.

\section{V.CONCLUSION}

Chinese tertiary EFL students face several difficulties when developing English speaking abilities, including external and internal difficulties. Due to the limits to the learning environment in China's university context and individual factors like motivation, personality and differences between L1 and L2, Chinese tertiary EFL students cannot effectively improve English speaking at university. Therefore, recommendations are given at the end of this article for Chinese tertiary EFL students and their English teachers to consider, including personal enhancement through activities like shadowing and 4-3-2 activity, and interactive ways where students can improve their speaking fluency and accuracy with the help of feedback given by language partners.

\section{REFERENCE}

[1] Li, C. (2012). An investigation of Chinese students' learning styles at an English-medium university in mainland china. Theory and Practice in Language Studies, 2(1), 6-13. Retrieved from https://search-proquestcom.helicon.vuw.ac.nz/docview/1348130428 accountid=14782

[2] Nelson, G. (2002). Cultural differences in learning styles: What do they mean? In J.M. Reid (ed.) Learning styles in the ESL/EFL classroom. Beijing: Beijing Foreign Language Teaching and Research Press. 3-18

[3] Zhao, G., \& Cao, Z. (2016). Contrastive study of English and Chinese word order from the perspective of figure-ground theory-A case study of the moonstone and its Chinese version. Journal of Language Teaching and $\begin{array}{lll}\text { Research, } & 7(2), & 389-397 .\end{array}$ doi:http://dx.doi.org.helicon.vuw.ac.nz/10.17507/jltr.0702.20.

[4] Yule, G. (2000). The study of language. 1st ed.Beijing: Foreign language teaching and research press.

[5] Ellis, R., \& Barkhuizen, G. P. (2005). Analysing learner language. Oxford: Oxford University Press.

[6] Lightbown, P. M., \& Spada, N. M. (2013). How languages are learned. Oxford: Oxford University Press.

[7] Selinker, L. (1972). Interlanguage. IRAL - International Review of Applied Linguistics in Language Teaching, 10(1-4). doi:10.1515/iral.1972.10.1-4.209

[8] International Phonetic Association. (1999). Handbook of the International Phonetic Association: A guide to the use of the International Phonetic Alphabet. Cambridge, UK: Cambridge University Press.

[9] Chang, J. (2002). Chinese speakers. Learner English, 310-324. doi:10.1017/cbo9780511667121.022

[10] Cook, V. (2011). Second language learning 67and language teaching. Beijing: Foreign language teaching and research press.

[11] James, D. G. H., van Doorn, J., McLeod, S., \& Esterman, A. J. (2008). Patterns of consonant deletion in typically developing children aged 3 to 7 years. International Journal of Speech- Language Pathology, 10, 179192.

[12] Gardner, R. C., \& Lambert, W. E. (1972). Attitudes and motivation in second-language learning. Rowley, MA: Newbury House Publishers.

[13] Buckledee, S. (2008). Motivation and Second Language Acquisition. ELOPE: English Language Overseas Per-spectives and Enquiries, 5(1-2), 159. doi:10.4312/elope.5.1-2.159-170

[14] Robinson, D., Gabriel, N., \& Katchan, O. (1994). Personality and second language learning. Personality and Individual Differences, 16(1), 143-157. doi:10.1016/0191-8869(94)90118-x

[15] Spielmann, G., \& Radnofsky, M. L. (2001). Learning Language under Tension: New Directions from a Qualita-tive Study. The Modern Language Journal, 85(2), 259-278. doi:10.1111/0026-7902.00108

[16] Yu, X., Law, S. P., Han, Z., Zhu, C., \& Bi, Y. (2011). Dissociative neural correlates of semantic processing of nouns and verbs in Chinese ... A language with minimal inflectional morphology. NeuroImage, 58(3), 912922.doi:http://dx.doi.org.helicon.vuw.ac.nz/10.1016/j.neuroimage.2011. 06.039

[17] Norman, D. A. (1976). Memory and attention (2nd ed.). New York: Wiley.

[18] Nation, I.S. (2013). What should every EFL teacher know? S.1.: Compass Publishing

[19] Lyster, R., \& Ranta, L. (1997). CORRECTIVE FEEDBACK AND LEARNER UPTAKE: Negotiation of Form in Communicative Classrooms. Studies in Second Language Acquisition, 19(1), 37-66. 